\title{
Cushing's syndrome: a structured short- and long-term management plan for patients in remission
}

Oskar Ragnarsson and Gudmundur Johannsson

Institute of Medicine, Sahlgrenska Academy, University of Gothenburg and Department of Endocrinology, Sahlgrenska University Hospital, Gröna Stråket 8, SE-41345 Gothenburg, Sweden

(Correspondence should be addressed to O Ragnarsson; Email: oskar.ragnarsson@medic.gu.se)

\begin{abstract}
One hundred years have passed since Harvey Williams Cushing presented the first patient with the syndrome that bears his name. In patients with Cushing's syndrome (CS), body composition and lipid, carbohydrate and protein metabolism are dramatically affected and psychopathology and cognitive dysfunction are frequently observed. Untreated patients with CS have a grave prognosis with an estimated 5-year survival of only 50\%. Remission can be achieved by surgery, radiotherapy and sometimes with medical therapy. Recent data indicate that the adverse metabolic consequences of CS are present for years after successful treatment. In addition, recent studies have demonstrated that health-related quality of life and cognitive function are impaired in patients with CS in long-term remission. The focus of specialised care should therefore be not only on the diagnostic work-up and the early postoperative management but also on the long-term follow-up. In this paper, we review the long-term consequences in patients with CS in remission with focus on the neuropsychological effects and discuss the importance of these findings for long-term management. We also discuss three different phases in the postoperative management of surgically-treated patients with CS, each phase distinguished by specific challenges: the immediate postoperative phase, the glucocorticoid dose tapering phase and the long-term management. The focus of the long-term specialised care should be to identify cognitive impairments and psychiatric disorders, evaluate cardiovascular risk, follow pituitary function and detect possible recurrence of CS.
\end{abstract}

European Journal of Endocrinology 169 R139-R152

\section{Introduction}

'Physical examination showed an undersized, kyphotic young woman of most extraordinary appearance. Her round face was dusky and cyanosed and there was an abnormal growth of hair. Her abdominous body had the appearance of a full-term pregnancy (1)'.
One hundred years have passed since Harvey Williams Cushing presented the first patient with the syndrome that bears his name (1). The patient was a 23-year-old woman with 'the most peculiar appearance'. Her abdomen was huge and the face was large and round with hypertrichosis and hyperpigmentation. She had gained weight and suffered from muscle weakness, back

\footnotetext{
Authors' profile:

Invited author: Gudmundur Johannsson is a Senior Consultant at the Department of Endocrinology at Sahlgrenska University Hospital, and Professor of Endocrinology at the Sahlgrenska Academy, University of Gothenburg, Sweden. Professor Johansson's major research interests include pituitary diseases, the importance of growth hormone in adults and adrenal insufficiency.

Oskar Ragnarsson is a consultant in endocrinology and the chief physician of the in-patient department of Endocrinology at Sahlgrenska University Hospital, Gothenburg, Sweden. His research relates to long-term consequences in patients with Cushing's syndrome in remission and patients receiving glucocorticoid replacement therapy.
} 
pain, irregular menstruation and elevated blood pressure. More than 20 years later, Cushing reported on additional 11 patients (2). Besides having similar clinical features, he also noted at autopsy that some of these patients had a small pituitary basophilic adenoma. Ten years later, Fuller Albright (3) stated that this clinical picture was caused by 'hyperadrenocorticism' with excess production of a 'sugar-hormone', today called glucocorticoids (GCs). He declared that the clinical state, irrespective of aetiology, should be called Cushing's syndrome (CS), and when caused by pituitary adenoma, it should be called Cushing's disease (CD).

\section{Aetiology}

CS is a clinical state caused by chronic overexposure of GCs (4). The typical features of CS are weight gain, central obesity, muscle and skin atrophy, osteoporosis, hypertension, impaired glucose tolerance, dyslipidemia, fatigue, depression and cognitive impairment (5). The most common cause of CS is iatrogenic, i.e. caused by pharmacological GC treatment (exogenous CS). Endogenous CS is an uncommon condition with an incidence rate between 1.8 and 2.4 patients/million per year. This incidence rate is mainly based on two studies: a nationwide Danish survey (6) and a study from New Zealand (7), supported by two other smaller studies $(8,9)$. The median age at diagnosis is 40 years with a female:male ratio of $3: 1(6,7)$. The most common cause of endogenous CS is CD (ACTHproducing pituitary adenoma), seen in $\sim 70 \%$ of patients with CS. Cortisol-producing adrenal adenomas and ectopic ACTH-producing tumours are less common, each accounting for $\sim 10-15 \%$ of cases.

\section{Treatment}

The first-line treatment for patients with $\mathrm{CD}$ is transsphenoidal pituitary surgery (TSS) and unilateral adrenalectomy for cortisol-producing adrenal adenoma (10). Unilateral adrenalectomy is curative in almost all patients with cortisol-producing adrenal adenoma and permanent adrenal insufficiency is rare. Conversely, hypopituitarism is common after TSS, with a range between 13 and 81\% $(11,12,13,14,15)$. Gonadal axis dysfunction and growth hormone (GH) deficiency are most commonly observed while central hypothyroidism and diabetes insipidus are less frequently observed $(15,16,17)$. The determining factors for the development of hypopituitarism are the size of the tumour (microadenoma vs macroadenoma), the surgical approach (adenomectomy vs hypophysectomy) and the experience of the surgeon, i.e. patients with microadenomas that are operated by an experienced neurosurgeon with selective adenomectomy have the lowest risk of hypopituitarism $(11,15)$. Furthermore,
14-29\% of patients with CD are not cured after TSS, and additionally, $9-25 \%$ of patients relapse at long-term follow-up after an initially successful treatment $(15,18$, 19). In a study on 184 patients with ACTH-producing microadenoma that achieved remission after TSS, $0.5,11$ and $26 \%$ of the patients relapsed after 1,3 and 5 years respectively (18). Second-line treatments, such as additional neurosurgical intervention, radiation therapy and/or bilateral adrenalectomy, may then become necessary, which further increases the risk for impaired pituitary function and compromised longterm outcome (20).

\section{Outcome}

\section{Mortality}

'The average duration of the disease from onset to death is slightly over five years (2)'.

Untreated patients with CS have a grave prognosis with an estimated 5 -year survival of only $50 \%(2,21)$. Even in patients that have received treatment for CS mortality increased, both in comparison with the normal population $(6,7,8,22,23)$ and with patients with non-functioning pituitary adenomas (24). However, achievement of remission is of fundamental importance as patients that are not cured have much worse prognosis than those in remission (6). In a recent paper on 343 patients with CS, mortality rate was higher than in the normal population (23). The greatest mortality risk was observed during the first year after treatment. However, the mortality risk at long-term follow-up was also significantly increased, with the hazard ratio being twice as high as in the control group (23). No difference in mortality rate was seen among patients treated for $\mathrm{CD}$ or cortisol-producing adrenal adenoma.

\section{Cardiovascular risk}

'The heart was enlarged and the aorta atheromatous (2)'.

Patients with active CS have adverse cardiovascular risk profile (25) and the majority have central obesity, hypertension, dyslipidemia and impaired glucose tolerance or diabetes mellitus (26). Echocardiographically, active CS is characterised by left ventricular hypertrophy and diastolic and systolic dysfunction $(27,28)$ that is at least partially explained by increased myocardial fibrosis (29). Although significant improvement is reported after cure, especially after treatment for cortisol-producing adrenal adenoma (26), a substantial number of patients still have an adverse cardiovascular risk profile (30). Indeed, $27 \%$ of patients treated for $\mathrm{CD}$ have atherosclerotic plaques at 5 years of follow-up, compared with only $3 \%$ of gender-, age- and BMI-matched controls (31). Conversely, left ventricular structure and function seem to be restored following treatment $(27,28,29)$. 
Coronary artery disease is more prevalent in patients with CS in remission compared with healthy individuals, especially women and younger patients (32). In another recently published population-based cohort study, increased risk for acute myocardial infarction, congestive heart failure, stroke and venous thromboembolism during the first year after treatment for CS, in comparison to the normal population, was observed (23). In the same study, the risk for acute myocardial infarction at long-term follow-up was nearly four times greater in the patients treated for CS. In agreement with the echocardiographic studies $(27,28,29)$, the risk for congestive heart failure seems not to be increased at long-term follow-up (23).

\section{Bone}

'A marked osteoporosis of the skeleton was found, it being easily possible to cut the vertebral bodies with a knife, the spongy part of the bone having largely disappeared (2)'.

Decreased bone mineral density (BMD), osteoporosis and osteoporotic fractures are important features of endogenous CS $(33,34)$. In patients with CS in remission, both longer duration of postoperative GC replacement therapy and duration of active disease are associated with low BMD (35). Prospective studies have demonstrated improved BMD following treatment of CS $(36,37,38)$. These studies are, however, limited by few patients, short follow-up time and/or lack of a control group. Two studies performed at long-term follow-up have presented conflicting results. In a prospective study on 18 patients with CS in remission from Norway, BMD Z-scores at all sites were normalised after 6 years (33), while in a cross-sectional study from Spain, 37 women with CS in remission for a mean time of 6 years had decreased BMD compared with matched controls (35).

\section{Quality of life, psychopathology and cognitive function}

'He found himself without energy, easily fatigued, unable to concentrate his mind on his work, and fits of unnatural irritability alternated with periods of depression (2)'.

\section{Patients with active CS}

Patients with active CS have markedly impaired quality of life (QoL), both in comparison with healthy individuals $(5,39)$ and patients with other pituitary tumours (40). Patients with active CS also have substantial psychiatric problems (41). Up to $80 \%$ of patients have generalised anxiety and $70 \%$ have major depression (42). Although not as common, manic or hypomanic symptoms may occur and be among the early manifestations of the disease (43).
Cognitive function is also negatively affected in patients with CS. In an early study on 35 patients with active $C S$, diffuse bilateral cerebral dysfunction was found in two-thirds of patients (44). Non-verbal visualideational and visual memory functions were most severely affected. In another study on 23 patients with CS, $66 \%$ had difficulty in concentration and $83 \%$ had memory impairments (45).

Morphological changes in the CNS are also reported in patients with active CS, including decreased total brain volume and hippocampal volume, compared with healthy subjects $(46,47)$. A significant correlation has been found between the degree of hypercortisolism, the extent of cognitive impairment and decreased hippocampal volume (46).

\section{Patients with CS in remission}

After treatment, QoL improves but is still worse than in controls (Fig. 1) (39, 48, 49, 50, 51). Furthermore, fatigue, which is one of the most common and distressing symptoms in patients with $\mathrm{CS}$, has been reported by $41-85 \%$ of patients at long-term follow-up after treatment $(39,49)$. In prospective studies, psychiatric abnormalities are reported to improve after treatment $(52,53)$. In one study, 33 patients with CS were examined by structured interviews as well as questionnaires before and at 3, 6 and 12 months after correction of hypercortisolism (53). Before treatment, two-thirds had significant psychopathology that was predominantly in the form of atypical depressive disorder. After remission, overall psychopathology decreased significantly to $54 \%$ at 3 months, $36 \%$ at

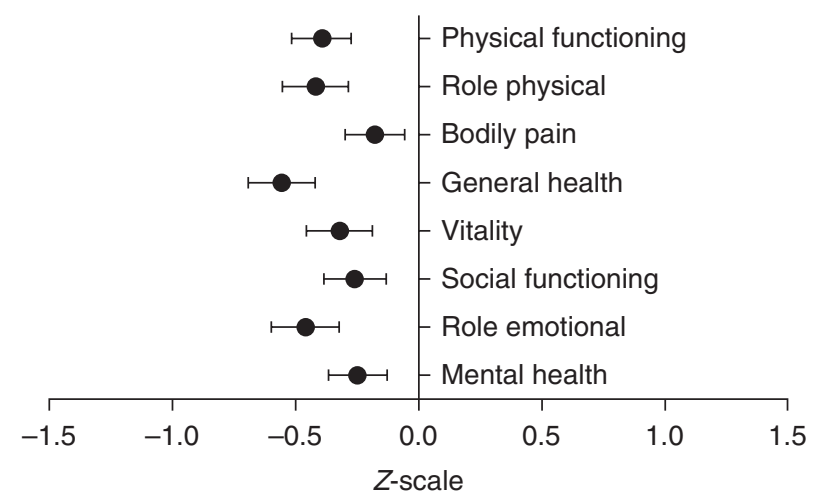

Figure 1 Results from a cross-sectional study on quality of life in 343 patients with Cushing's syndrome (CS) in remission (mean \pm s.D. time in remission $11.8 \pm 4.9$ years). Data are presented as mean \pm $95 \%$ Cls. Patients with CS in remission had lower scores on all individual domains of the short-form 36 questionnaire compared with age- and sex-matched control values from the USA population (zero-line). From Lindsay JR, Nansel T, Baid S, Gumowski J \& Nieman LK. Long-term impaired quality of life in Cushing's syndrome despite initial improvement after surgical remission. Journal of Clinical Endocrinology and Metabolism 200691 447-453. Adapted with permission from Endocrine Society. 
6 months and $24 \%$ at 12 months. Even at long-term follow-up, patients with a mean duration of remission of 11 years showed an increased prevalence of apathy, irritability, anxiety and depression (54).

Improvements in cognitive function $(55,56,57)$ and morphological brain changes $(55,58,59)$ occur following treatment. However, the number of patients in these studies was limited (between 13 and 33 patients) and the follow-up times were short (1-2 years) (Table 1). Recently, cognitive function at long-term follow-up in patients with CS in remission has been addressed. In a study from The Netherlands, cognitive function in
74 patients with $\mathrm{CD}$ in remission was compared with that in 74 healthy individuals and 54 patients previously treated for a non-functioning pituitary adenoma (60). The mean \pm s.D. duration of remission was $13 \pm 13$ years (range $1-51$ years). The cognitive testing was mainly focused on memory and executive functioning and showed worse performance in patients with CD compared with both control groups. Even global cognitive functioning, evaluated using the Mini Mental State Examination, was significantly worse in the CD patients. In another recent study, memory, hippocampal volume and brain grey matter volume were evaluated in

Table 1 Summary of studies on cognitive function in patients with CS in remission.

\begin{tabular}{|c|c|c|c|c|c|}
\hline Study & Subjects & Main variables & Design & Time at evaluation & Main findings \\
\hline (118) & $\begin{array}{l}25 \mathrm{CD} \\
60 \text { controls }\end{array}$ & $\begin{array}{l}\text { Memory, learning, } \\
\text { visual scanning, } \\
\text { divided attention, } \\
\text { motor speed, } \\
\text { information-processing } \\
\text { speed and verbal } \\
\text { fluency }\end{array}$ & Prospective & $\begin{array}{l}\text { Pre- and post treatment } \\
\text { ( } 8 \text { of } 25 \text { patients } \\
\text { re-evaluated } \\
6 \text { months after } \\
\text { treatment) }\end{array}$ & $\begin{array}{l}\text { Eight patients re-tested } 6 \\
\text { months after treatment } \\
\text { showed significant } \\
\text { improved memory and } \\
\text { attention but not in other } \\
\text { cognitive functions } \\
\text { compared with controls }\end{array}$ \\
\hline (56), USA & $\begin{array}{l}29 \mathrm{CD} \\
3 \mathrm{EAS} \\
1 \mathrm{CPAA} \\
17 \text { controls }\end{array}$ & $\begin{array}{l}\text { Memory, learning, } \\
\text { problem solving, } \\
\text { motor speed, visual } \\
\text { construction ability } \\
\text { and IQ }\end{array}$ & Prospective & $\begin{array}{l}\text { Pre-treatment and at } \\
3,6 \text { and } 12 \text { months } \\
\text { after treatment }\end{array}$ & $\begin{array}{l}\text { No significant improvement } \\
\text { in cognitive functioning. } \\
\text { Trend of lower IQ at } \\
\text { baseline. For some sub- } \\
\text { scales of IQ there was a } \\
\text { positive relationship with } \\
\text { recovery of the HPA axis } \\
\text { and a negative relation- } \\
\text { ship with duration of CS }\end{array}$ \\
\hline (57), Canada & $\begin{array}{l}9 \mathrm{CD} \\
4 \text { CPAA } \\
13 \text { controls }\end{array}$ & $\begin{array}{l}\text { Attention, visual proces- } \\
\text { sing, visuospatial } \\
\text { processing, memory, } \\
\text { reasoning and verbal } \\
\text { fluency }\end{array}$ & Prospective & $\begin{array}{l}\text { Pretreatment and } \\
1 \text { year after } \\
\text { treatment }\end{array}$ & $\begin{array}{l}\text { Visual processing and verbal } \\
\text { fluency improved after } \\
\text { treatment but no other } \\
\text { cognitive functions }\end{array}$ \\
\hline (119) & $27 \mathrm{CD}$ & $\begin{array}{l}\text { Memory, learning, } \\
\text { attention, working } \\
\text { memory and verbal } \\
\text { fluency }\end{array}$ & Prospective & $\begin{array}{l}\text { Pretreatment and at } \\
3-5,6-12 \text { and } \\
13-18 \text { months after } \\
\text { treatment }\end{array}$ & $\begin{array}{l}\text { Memory, learning and verbal } \\
\text { fluency improved after } \\
\text { treatment while attention } \\
\text { and working memory } \\
\text { did not }\end{array}$ \\
\hline $\begin{array}{l}\text { (60), The } \\
\text { Netherlands }\end{array}$ & $\begin{array}{l}74 \mathrm{CD} \\
74 \text { controls } \\
54 \text { NFPA }\end{array}$ & $\begin{array}{l}\text { Global cognitive } \\
\text { functioning, memory, } \\
\text { learning, working } \\
\text { memory and verbal } \\
\text { fluency }\end{array}$ & Cross-sectional & $\begin{array}{l}\text { Mean } \pm \text { s.D. duration of } \\
\text { remission } 13 \pm 13 \\
\text { years (range } 1-51 \\
\text { years) }\end{array}$ & $\begin{array}{l}\text { Patients with CD had worse } \\
\text { global cognitive function- } \\
\text { ing, memory, learning, } \\
\text { working memory and } \\
\text { verbal fluency compared } \\
\text { with patients with NFPA }\end{array}$ \\
\hline (61), Spain & $\begin{array}{l}25 \mathrm{CD} \\
7 \mathrm{CPAA} \\
1 \mathrm{EAS} \\
34 \text { controls }\end{array}$ & $\begin{array}{l}\text { Visual and verbal } \\
\text { memory }\end{array}$ & Cross-sectional & $\begin{array}{l}11 \text { of } 33 \text { patients had } \\
\text { active CS. Mean } \pm \text { s.D. } \\
\text { duration of remission } \\
\text { for the remaining } 22 \\
\text { was } 5.5 \pm 3.7 \text { years }\end{array}$ & $\begin{array}{l}\text { Memory performance did not } \\
\text { differ between active CS } \\
\text { and CS in remission. } \\
\text { Verbal and visual memory } \\
\text { worse in CS patients } \\
\text { (active and in remission } \\
\text { pooled) in comparison to } \\
\text { controls }\end{array}$ \\
\hline (49), Sweden & $\begin{array}{l}43 \mathrm{CD} \\
12 \text { CPAA } \\
55 \text { controls }\end{array}$ & $\begin{array}{l}\text { Working memory, } \\
\text { attention, information- } \\
\text { processing speed, } \\
\text { verbal fluency, reading } \\
\text { speed, alerting, } \\
\text { orienting and executive } \\
\text { control }\end{array}$ & Cross-sectional & $\begin{array}{l}\text { Median (interquartile } \\
\text { range) duration of } \\
\text { remission was } 13 \\
(5-19) \text { years }\end{array}$ & $\begin{array}{l}\text { Attention, spatial orienting, } \\
\text { alerting, working memory, } \\
\text { verbal fluency and reading } \\
\text { speed all worse in } \\
\text { comparison with controls, } \\
\text { independent of scores for } \\
\text { depression and anxiety } \\
\text { and fatigue }\end{array}$ \\
\hline
\end{tabular}

CD, Cushing's disease; CPAA, cortisol-producing adrenal adenoma; CS, Cushing's syndrome; EAS, ectopic ACTH syndrome; HPA, hypothalamus-pituitaryadrenal; IQ, intelligence quotient; NFPA, non-functioning pituitary adenoma. 
11 patients with active CS, 22 patients with CS in remission (mean \pm s.D. time of biochemical control 7.3 years \pm 2.4 ) and 34 matched controls (61). No difference in cognitive function or brain volumes was seen between patients with active CS or patients in remission wherefore the groups were pooled together in the analysis. In patients with CS, verbal memory and visual memory were found to be impaired compared with controls. Interestingly, brain grey matter volumes, evaluated using magnetic resonance imaging, were decreased in patients with CS, although no significant difference in hippocampal volume was seen (61). In children with CS, a decline in cognitive function has been reported following cure (62). In a study on 11 children with CS, 8-16 years old, no difference in intelligence quotient (IQ) or psychopathology was seen before treatment when compared with controls, although smaller cerebral volumes, larger ventricles and smaller amygdale were documented (62). One year after treatment, despite reversal of cerebral atrophy, a decline in IQ and school performance was observed. This is in a disagreement with the findings in adults. Self-perceived health-related QoL in paediatric CS patients was also been shown to be impaired. One year postoperation improvement was seen, although residual impairment was still observed (63).

We have recently demonstrated that various domains of cognitive function are compromised in patients with CS after long-term remission (49). In a cross-sectional study, cognitive function in 43 patients previously treated for $\mathrm{CD}$ and 12 patients for cortisol-producing adrenal adenoma was compared with that in 55 controls, matched for age, gender and educational level. Cognitive function was studied using a standardised neuropsychological test: the Attentional Network Test. Median (interquartile range) duration of remission was 13 (5-19) years. In a multivariate analysis, attention, spatial orienting, alerting, working memory, verbal fluency and reading speed were diminished in comparison with controls, independent of scores for affective disorder and fatigue (Fig. 2). No overall difference in outcome was seen between patients in long-term remission for $\mathrm{CD}$ and cortisol-producing adrenal adenoma. Furthermore, the results on most cognitive tests were similar for patients with and without hormone deficiency, previous radiotherapy and GC replacement. The results from our study demonstrate two important findings. First, cognitive function is not only temporarily affected at short-term follow-up but seems to be a permanent state. Secondly, patients with CS in remission have impairment in various domains of cognitive function and not only in hippocampal function that has previously received greatest attention $(60,61)$.

\section{The aetiology of cognitive dysfunction in patients with CS}

The reason for the neurocognitive impairment in patients with CS is not clearly understood. It is also
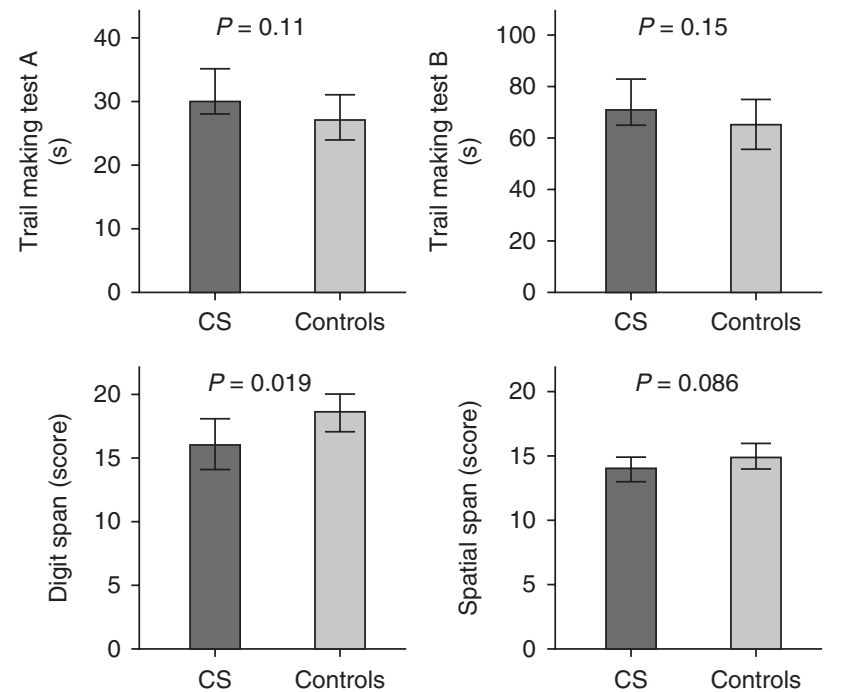
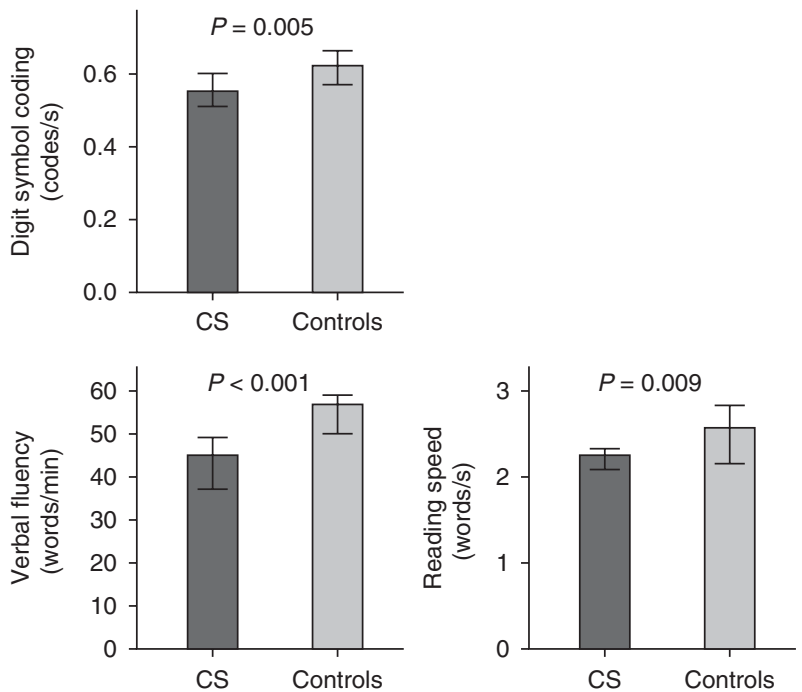

Figure 2 Results from a cross-sectional study on cognitive function in 55 patients with Cushing's syndrome (CS) in remission (median (interquartile range) duration of remission 13 (5-19) years) and 55 healthy controls, matched for age, gender and educational level. The bar charts demonstrate median score on i) trail making test A, ii) trail making test $B$ (visual scanning, divided attention and motor speed), iii) digit symbol coding test (speed processing), iv) digit span test (auditory attention and working memory), v) spatial span test (visual attention and working memory), vi) verbal fluency test and vii) reading speed test, in patients with CS in remission. $P$ values are obtained from multiple regression analysis adjusted for scores for fatigue, depression and anxiety. Error bars represent $95 \% \mathrm{Cl}$. From $\mathrm{Ragnarsson} \mathrm{O}$, Berglund $\mathrm{P}$, Eder DN \& Johannsson G. Long-term cognitive impairments and attentional deficits in patients with Cushing's disease and cortisolproducing adrenal adenoma in remission. Journal of Clinical Endocrinology and Metabolism 2012 97 E1640-E1648. Reproduced with permission from Endocrine Society. 
surprising how differently the postoperative course evolves in patients with CS. Some patients experience recovery relatively shortly after surgery while for others it can take years. Unfortunately, there are also patients that after many years in remission are still suffering from the distressing sensation of chronic fatigue and impaired general well-being. The reason for this discrepancy is unknown. Potential explanations include concomitant neuropsychiatric problems such as anxiety and depression, noted in up to $24 \%$ of patients 1 year after curative treatment (53), inadequate replacement therapy of postoperative hormone deficiencies commonly seen after TSS $(11,12,13,14)$ and consequences of pituitary radiation therapy. In our study, none of these potential confounders were found to have a statistically significant impact on cognitive performance (49). The number of patients in the subgroup analyses was, however, less and the results should be interpreted with caution. Another possible explanation could be a general effect of the pituitary disease per se. However, when patients with $\mathrm{CD}$ in remission are compared with those having other forms of pituitary diseases, cognitive function (60) and QoL (40) are significantly worse in the former group, arguing against that the pituitary disease itself plays a major role in this context. Thus, our results (49) in addition to the two other recently published papers $(60,61)$ suggest that long-term exposure to excess GC plays a causative role in the long-term cognitive consequences of CS.

GCs have a great impact on the CNS through their binding and activation of the GC receptor, which is widely expressed in the brain (64). GCs also activate the mineralocorticoid receptors that are found in more restricted areas such as the hippocampus, amygdala and prefrontal cortex - collectively referred to as the limbic system. The limbic system is of great importance for cognitive function. The hippocampus is the main centre for memory and learning. The amygdala is the principal emotional centre while the prefrontal cortex is involved in behavioural inhibition, decision-making, executive function and working memory (65). The enzyme 11ß-hydroxysteroid dehydrogenase type 1 (11 $\beta$-HSD1), an enzyme that converts the inactive metabolite cortisone to the active compound cortisol, is also widely distributed in the brain. On the other hand, $11 \beta$-HSD2, with the opposite function, is only scarcely expressed. During states of GC excess, the protective role of $11 \beta-H S D 2$ is therefore absent, and areas that express GC and mineralocorticoid receptors abundantly, such as the limbic system, may therefore be especially vulnerable. In rodents, short-term GC administration leads to atrophy of dendrites in hippocampal neurons, changes that are reversible when GCs are withdrawn (66). Longer exposure to high GC levels causes hippocampal degeneration, partly due to loss of neurons (66). These observations support that the cognitive dysfunction observed in patients with CS may be caused by irreversible changes in the CNS. In a study on 18 patients with CS in remission, evaluated with proton magnetic resonance spectroscopy $8.5 \pm 3.2$ years after successful treatment, brain metabolites in the left and right hippocampus were measured (67). In comparison to healthy controls, concentrations of $\mathrm{N}$-acetylaspartate were lower and concentrations of glutamate and glutamine were higher in patients with CS in remission, suggesting neuronal dysfunction/loss and glial proliferation (as a repair mechanism after neuronal dysfunction) respectively (67).

Patients with mild dementia (68) and Alzheimer's disease (69) have increased endogenous cortisol production. In patients with neurodegenerative diseases, analysis of biomarkers in cerebrospinal fluid is useful in the clinical work-up and differentiates between different forms of dementias $(70,71)$. In patients with CS in remission, the pattern of neurodegenerative and inflammatory biomarkers in cerebrospinal fluid does not differ from healthy subjects (72). The underlying mechanism of the cognitive deficits therefore seems to be different from those seen in neurodegenerative disorders.

It has been suggested that the duration of active CS and the degree of hypercortisolism - i.e. patients that have had a longer duration of, or more extensive, hypercortisolaemia, may have worse outcomes. In fact, lower BMD (35), adverse cardiovascular risk (30), increased mortality (73) as well as worse cognitive function and reduced hippocampal volume (61) have been demonstrated to be associated with longer duration of hypercortisolaemia. Exploring this topic is, however, methodologically difficult for number of reasons. First, endogenous CS is a rare disorder and designing a sufficiently powered study for this reason would be difficult. Secondly, it is difficult to estimate the duration of time with active disease. This will always be done retrospectively, and as the symptoms and signs of CS usually develop insidiously, it is difficult to estimate the exact time-point of debut. In addition, there is a risk that patients with the greatest suffering overestimate their time with active CS. Thirdly, the evaluation of the extent of hypercortisolaemia is difficult. Both urinary free cortisol and serum cortisol can vary from one time to another and are, moreover, generally not good predictors of GC exposure in the tissues. An ideal method would be a measurement of tissue response to GC, a method that currently does not exist.

\section{Management of patients with CS in remission}

'He had been pleading for an exploratory operation which was considered impracticable, but in view of the growing conviction that his trouble must be due to a basophil adenoma, which might conceivably be amenable to radiation, he was given four X-ray treatments (1)'. 
Table 2 Summary of the three phases of postoperative management of surgically-treated patients with Cushing's syndrome (CS).

Immediate postoperative management (first 1-2 weeks after treatment)

GC dose tapering stage (first $1-2$ years after treatment)

Long-term management
Evaluate if remission has been achieved by measuring serum cortisol at 0700-0900 h, after hydrocortisone withdrawal for $24 \mathrm{~h}$.

Cortisol concentrations below $50 \mathrm{nmol} / \mathrm{l}$ are compatible with remission and low risk for recurrence.

Introduce GC replacement to successfully treated patients with initial hydrocortisone dose of 20-40 mg/day in two to three divided doses.

Inform the patient about the risk for development of the steroid withdrawal syndrome.

Give thorough information on the need for increased GC dose during intercurrent illness.

Evaluate anterior and posterior pituitary function.

Reduce the initial hydrocortisone dose by $5 \mathrm{mg}$ every 3-6 weeks until a physiological dose of 10-20 mg/day has been reached.

Thereafter, perform ACTH stimulation every 3-6 months to evaluate recovery of the HPA axis.

When unstimulated or stimulated serum cortisol exceeds $500 \mathrm{nmol} / \mathrm{l}$, hydrocortisone replacement should be discontinued.

Inform the patient about the risk for development of the steroid withdrawal syndrome during dose tapering. Symptoms due to steroid withdrawal need to be differentiated from symptoms of adrenal insufficiency.

Give thorough information on the need for increased GC dose during intercurrent illness.

Evaluate biochemical and/or clinical signs of recurrence of CS at least annually.

Assess menstrual cycle, sexual functions and pituitary function tests at least yearly and initiate adequate hormone replacement when indicated.

Consider evaluation of possible growth hormone deficiency 1-2 years postoperatively.

For patients with remaining adrenal insufficiency, avoid supraphysiological GC replacement doses.

Evaluate cardiovascular risk profile yearly and treat hypertension, hyperglycaemia and dyslipidemia when present.

Evaluate bone health regularly and treat osteoporosis when indicated.

Assess potential cognitive impairments and/or psychiatric disorders annually by evaluating subjective complaints of fatigue, memory impairments, concentration difficulties, attention deficits, anxiety and/or depressed mood.

When cognitive dysfunction is present, rule out treatable causes such as hypopituitarism, other endocrine disorders, hormonal overtreatment, vitamin deficiencies, depression and/or anxiety.

Support patients with cognitive impairment and discuss coping strategies and social support.
All patients that are treated for CS need oriented longterm follow-up by a qualified physician. Practically, the postoperative management can be divided into three different stages with different focus and challenges: i) an immediate postoperative management, ii) a GC dose tapering stage and iii) long-term management (Table 2).

\section{Phase 1: immediate postoperative management: first 1-2 weeks after treatment}

Within a week after TSS for CD, achievement of remission should be evaluated. Although no consensus exists, a low postoperative serum cortisol concentration $(<50 \mathrm{nmol} / \mathrm{l})$, measured after a temporary cessation of GC replacement, is commonly thought to be compatible with remission $(10,13,74,75,76)$. During the early postoperative phase, there is no need to perform an ACTH test and, in fact, should be avoided as false-positive cortisol response may be expected. In surgically-treated patients with cortisol-producing adrenal adenoma, assessment of remission is not required.

Almost all CS patients that achieve remission need GC replacement, both after TSS and adrenalectomy. From the published literature, the initial dose of hydrocortisone given to patients with CS in early remission varies between 20 and $30 \mathrm{mg} /$ day $(77,78)$. The initial hydrocortisone dose given to children at the National Institute of Health is $8-12 \mathrm{mg} / \mathrm{m}^{2}$ in two divided doses (79). In adults, doses between 12 and $15 \mathrm{mg} / \mathrm{m}^{2}$ have been recommended (10).

At our institute, all patients with CS receive parenteral hydrocortisone the first 2 days after surgical treatment and are thereafter switched to tablets. On postoperative days 4-6, after hydrocortisone withdrawal for $24 \mathrm{~h}$, evaluation of remission is performed in patients treated for CD by measuring serum cortisol. If remission is confirmed, hydrocortisone is reintroduced. The decline in circulating levels of cortisol after successful treatment for CS is often dramatic. Postoperatively, a substantial number of patients do therefore, despite GC replacement, experience symptoms compatible with GC deficiency, a phenomenon called steroid withdrawal syndrome (80). Occasionally, these symptoms can be misinterpreted as a true GC deficiency and subsequently lead to administration of unnecessarily high GC doses. In our experience, the hydrocortisone doses that are initially required vary, ranging between 20 and $40 \mathrm{mg}$ /day in two divided doses. In general, patients with high preoperative urinary free cortisol require higher hydrocortisone doses $(30 \mathrm{mg} /$ day) and patients with normal or moderately elevated urinary free cortisol require lower doses 


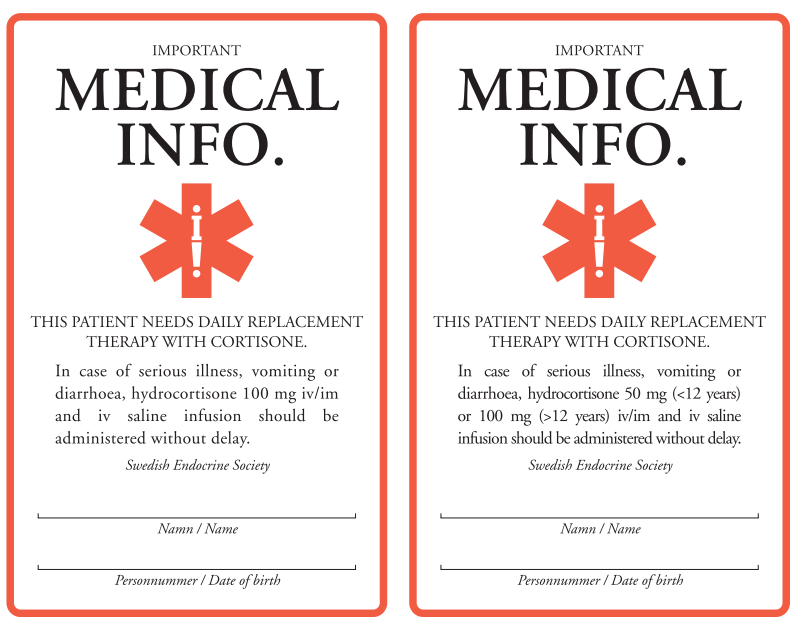

Figure 3 The Swedish medical emergency card for patients with adrenal insufficiency. From Dahlqvist $P$, Bensing $S$, Ekwall O, Wahlberg J, Bergthorsdottir R \& Hulting AL. A national medical emergency card for adrenal insufficiency. A new warning card for better management and patient safety. Lakartidningen 2011108 2226-2227.

(20 mg/day). In a small subgroup of patients with severe steroid withdrawal syndrome, initial hydrocortisone doses as high as $40 \mathrm{mg} /$ day may be required. All patients in remission that require GC replacement are thoroughly informed about the need of increased GC dose during intercurrent illness and receive a medical emergency card (Fig. 3) (81).

Active CS is frequently accompanied by hypogonadism (82) and central hypothyroidism (83). As gonadal $(84,85)$ and thyroid function $(83,86)$ normalise in the majority of the patients during the first few months postoperatively, only patients with overt hypothyroidism and/or hypogonadism should receive replacement therapy in the immediate postoperative period.

\section{Phase 2: GC dose tapering: first 1-2 years after treatment}

In patients with $\mathrm{CS}$ in remission, GC doses should be successively tapered with the ultimate goal to regain normal hypothalamus-pituitary-adrenal (HPA) axis function. In a retrospective study on 32 patients with CS in remission, 12 of 18 patients with CD recovered within a median follow-up time of 24 months (range 7-54 months) whereas six did not recover within 3-12 years (77). Eleven of 14 patients with cortisolproducing adenoma recovered within 24 months (10-48 months) whereas three did not recover within 4-10 years. In another study on patients with CD, a median time of 15 months (range 9-22 months) was required to recover a normal cortisol response to ACTH stimulation and 19 months (range 12-24 months) to allow discontinuation of hydrocortisone (87).

In previous studies, various GC tapering schemes have been used $(77,78,79)$. In our experience, it is highly individual how fast GC tapering can be done and should mainly be guided by clinical status of the patient. In general, the initial hydrocortisone dose should be reduced by $5 \mathrm{mg}$ every 3-6 weeks until a nearphysiological dose of 10-20 mg/day has been reached. Thereafter, ACTH stimulation, after temporary interruption of GC treatment for 16-24 h, should be performed every 3-6 months to evaluate recovery of the HPA axis. When unstimulated or stimulated serum cortisol exceeds $500 \mathrm{nmol} / \mathrm{l}$, hydrocortisone replacement should be discontinued (10).

During the GC tapering period, and after discontinuation of hydrocortisone, patients experience symptoms due to the steroid withdrawal syndrome (80). Subjectively, the symptoms cannot be clinically differentiated from true GC deficiency, i.e. fatigue, abdominal discomfort, nausea, muscle weakness and arthralgias. Again, symptoms due to the steroid withdrawal syndrome may therefore lead to administration of unnecessarily high GC doses for very long periods of time. Thus, a major challenge during this stage is to differentiate between the withdrawal symptoms and symptoms of adrenal insufficiency. Objectively, steroid withdrawal syndrome is characterised by normal concentrations of cortisol in serum and normal urinary cortisol excretion while GC deficiency is accompanied by low cortisol concentrations. Furthermore, withdrawal symptoms usually improve or resolve within a few weeks after dose reduction. In patients that find the withdrawal symptoms unacceptably distressing a temporary dose increment can be considered with a new trial of dose reduction 3-6 weeks later.

During the period of GC tapering, biochemical and/or clinical signs of recurrence of CS should be simultaneously monitored. In patients with suspected recurrence, hydrocortisone should be discontinued and urinary free cortisol measured and dexamethasone suppression test performed. Similarly, patients with subnormal thyroid and gonadal status during the immediate postoperative period should receive regular monitoring of their anterior pituitary function.

\section{Phase 3: long-term management}

Owing to the relatively high risk for recurrence after an initially successful surgery for CD $(15,18,19)$, patients should be evaluated clinically and biochemically at least annually to confirm sustained long-term remission. As recurrence can occur even decades after treatment, a lifelong follow-up is needed (18). Although late recurrence after unilateral adrenalectomy is rare, a long-term surveillance for cortisol-producing adrenal adenoma has also been recommended $(88,89)$. The current standard criteria for evaluating remission are based on a normal urinary free cortisol and/or a normal suppression of the HPA axis using the low-dose dexamethasone suppression test. These criteria are, however, not taken into consideration if normal cortisol 
diurnal rhythm and the response of the HPA axis during psychological and physical stress are restored. For patients with confirmed recurrence, additional treatment is required (reoperation, radiotherapy or medical therapy) (20).

Pituitary hormone deficiencies are relatively common after TSS $(11,12,13,14)$. Patients with hypopituitarism have increased cardiovascular morbidity and mortality $(90,91)$. The cause is probably multifactorial; the unfavourable metabolic profile due to $\mathrm{GH}$ deficiency (92), the quality of gonadal replacement, treatment with pituitary radiotherapy (93) and underlying diagnosis of CD (94) may be important factors. A thorough evaluation of pituitary function is therefore mandatory in all patients with CS in remission and adequate hormone replacement should be initiated when indicated.

GH secretion is compromised in patients with CD for a long period after remission has been achieved $(16,17)$. Evaluation of GH deficiency should therefore not be performed earlier than 1 or 2 years after successful treatment (95). In patients with confirmed GH deficiency, replacement therapy should be strongly considered. QoL and cognitive function are negatively affected by $\mathrm{GH}$ deficiency and improves with $\mathrm{GH}$ replacement $(96,97,98)$. Furthermore, for patients with $\mathrm{CS}$ in remission that also have GH deficiency, improved metabolic profiles have been demonstrated with $\mathrm{GH}$ replacement (96).

Between 25 and $51 \%$ of patients treated for CS require chronic GC replacement therapy, for both those patients treated for CD and cortisol-producing adrenal adenoma $(49,54,77,79)$. The relative risk of death in patients with primary adrenal insufficiency receiving GC replacement therapy is twofold higher than in the background population $(99,100)$. Patients with acromegaly and ACTH insufficiency that receive a daily hydrocortisone dose of more than $25 \mathrm{mg}$ /day have increased mortality (101). Hence, there are indications that GC replacement may influence mortality in patients with adrenal insufficiency. It has been shown that the endogenous cortisol production is $\sim 10 \mathrm{mg} / \mathrm{m}^{2}$ per day, corresponding to $15-20 \mathrm{mg}$ oral hydrocortisone (102). Adverse metabolic profile (103), lower BMD (104, 105) and impaired QoL $(106,107)$ have been associated with high GC replacement doses. In GC-replaced patients with hypopituitarism, receiving a mean hydrocortisone dose of $24 \mathrm{mg}$, a dose-related increase in BMI, triglycerides and total cholesterol and LDL cholesterol concentrations was demonstrated (103). Also, as recently indicated, the cortisol exposure time profile during GC replacement may also be important for the metabolic outcome (108). For patients with $\mathrm{CS}$ in remission that have adrenal insufficiency, supraphysiologic GC doses should therefore be avoided. This is often difficult to avoid in the immediate postoperative phase, but the dose should be brought down to physiological daily doses as fast as possible. Simultaneously, GC doses should not be tapered too fast and the long-term maintenance dose should not be too low risking acute adrenal crisis. In fact, patients with hypopituitarism and concomitant ACTH deficiency may have excess mortality due to adrenal crisis in response to acute stress and intercurrent illness (109).

The cardiovascular risk profile should be evaluated at least yearly in all patients that have been treated for CS by measuring weight, height, BMI, waist circumference, blood pressure, lipid profile and fasting glucose. When hypertension, hyperglycaemia and dyslipidemia are present, these should be adequately treated. A more aggressive approach should be considered for patients with CS in remission in accordance with guidelines for other high-risk groups such as diabetes mellitus (110) and has been suggested for patients with acromegaly (111).

Patients with pituitary insufficiency also have reduced BMD and an increased fracture rate (112, 113, $114,115)$. Among many potential explanations for these observations is the use of supraphysiological GC doses, inadequate sex hormone replacement therapy and untreated GH deficiency (116). Bone health should therefore be regularly evaluated in patients with CS in remission and management for osteoporosis initiated when indicated.

Reduced QoL, cognitive dysfunction and chronic fatigue are still present in a substantial number of patients with CS in remission despite apparently adequate hormonal replacement therapy or in hormonally intact patients $(39,49,60,61)$. In the most severely affected patients, the neuropsychological problems result in decreased working capacity and social isolation (49). An assessment of potential cognitive impairments and/or psychiatric disorders should be performed annually by evaluation of subjective complaints of fatigue, memory impairments, concentration difficulties, attention deficits, anxiety and/or depressed mood. In cases where psychiatric disorders are suspected, oriented evaluation should be performed and when disorders such as depression and/or anxiety are present, these should be promptly treated. Unfortunately, at present, there is no specific treatment available that alleviates the cognitive dysfunction or fatigue in patients with CS in remission. It is, however, important to rule out other treatable causes such as hypopituitarism, other endocrine disorders, hormonal overtreatment, vitamin deficiencies and psychiatric disorders. Supporting is also important, i.e. that the patients are heard and that they feel that the caregiver understands their distressing problems. It has been reported that patients with $\mathrm{CD}$ in remission use different and less effective coping strategies compared with healthy controls (117). Indeed, their coping is less active and they seek social support less often than controls. Patients with CS in remission should therefore be encouraged to use more active coping strategies and to seek social support (117). 


\section{Conclusion}

In recent years, several studies have demonstrated that patients with CS in remission have adverse cardiovascular risk profile, bone health, impaired QoL and cognitive dysfunction, even many years after successful treatment. In accordance with the diagnostic work-up and management of patients with active CS, an oriented long-term follow-up plan by a qualified medical team is required for all patients that are successively treated for CS. Careful information about each stage in the management should be provided, i.e. the immediate postoperative period, the $\mathrm{GC}$ dose tapering stage and the long-term follow-up.

\section{Declaration of interest}

O Ragnarsson has nothing to declare. G Johannsson is a consultant for Viropharma and Astra Zeneca and has received lecture fees from Novo Nordisk, Eli Lilly, Merck Serono, Otsuka and Pfizer.

\section{Funding}

This research did not receive any specific grant from any funding agency in the public, commercial or not-for-profit sector.

\section{References}

1 Cushing H. The pituitary body and its disorders, clinical states produced by disorders of the hypophysis cerebri. Philadelphia, London: J.B. Lippincott Company, 1912.

2 Cushing H. The basophil adenomas of the pituitary body and their clinical manifestations (pituitary basophilism). Bulletin of the Johns Hopkins Hospital 193250 137-195.

3 Albright F. Cushing's syndrome; its pathology and physiology, its relationship to the adrenogenital syndrome, and its connection with the problem of the reaction of the body to injurious agents. Harvey Lectures 194338 123-186.

4 Newell-Price J, Bertagna X, Grossman AB \& Nieman LK. Cushing's syndrome. Lancet $2006 \quad \mathbf{3 6 7} \quad 1605-1617$. (doi:10.1016/S0140-6736(06)68699-6)

5 Valassi E, Santos A, Yaneva M, Toth M, Strasburger CJ, Chanson P, Wass JA, Chabre O, Pfeifer M, Feelders RA et al. The European Registry on Cushing's syndrome: 2-year experience. Baseline demographic and clinical characteristics. European Journal of Endocrinology 2011165 383-392. (doi:10.1530/EJE11-0272)

6 Lindholm J, Juul S, Jorgensen JO, Astrup J, Bjerre P, Feldt-Rasmussen U, Hagen C, Jorgensen J, Kosteljanetz M, Kristensen L et al. Incidence and late prognosis of Cushing's syndrome: a population-based study. Journal of Clinical Endocrinology and Metabolism 200186 117-123. (doi:10.1210/jc.86.1.117)

7 Bolland MJ. Holdaway IM, Berkeley JE, Lim S, Dransfield WJ, Conaglen JV, Croxson MS, Gamble GD, Hunt PJ \& Toomath RJ. Mortality and morbidity in Cushing's syndrome in New Zealand. Clinical Endocrinology 201175 436-442. (doi:10.1111/j.13652265.2011.04124.x)

8 Etxabe J \& Vazquez JA. Morbidity and mortality in Cushing's disease: an epidemiological approach. Clinical Endocrinology 1994 40 479-484. (doi:10.1111/j.1365-2265.1994.tb02486.x)

9 Arnardottir S \& Sigurjonsdottir HA. The incidence and prevalence of Cushing's disease may be higher than previously thought: results from a retrospective study in Iceland 1995 through 2009. Clinical Endocrinology 2011 74 792-793.
10 Biller BM, Grossman AB, Stewart PM, Melmed S, Bertagna X, Bertherat J, Buchfelder M, Colao A, Hermus AR, Hofland LJ et al. Treatment of adrenocorticotropin-dependent Cushing's syndrome: a consensus statement. Journal of Clinical Endocrinology and Metabolism 200893 2454-2462. (doi:10.1210/ jc. 2007-2734)

11 Rees DA, Hanna FW, Davies JS, Mills RG, Vafidis J \& Scanlon MF. Long-term follow-up results of transsphenoidal surgery for Cushing's disease in a single centre using strict criteria for remission. Clinical Endocrinology $2002 \quad 56 \quad 541-551$. (doi:10.1046/j.1365-2265.2002.01511.x)

12 Salenave S, Gatta B, Pecheur S, San-Galli F, Visot A, Lasjaunias P, Roger P, Berge J, Young J, Tabarin A et al. Pituitary magnetic resonance imaging findings do not influence surgical outcome in adrenocorticotropin-secreting microadenomas. Journal of Clinical Endocrinology and Metabolism 200489 3371-3376. (doi:10. 1210/jc.2003-031908)

13 Trainer PJ, Lawrie HS, Verhelst J, Howlett TA, Lowe DG, Grossman AB, Savage MO, Afshar F \& Besser GM. Transsphenoidal resection in Cushing's disease: undetectable serum cortisol as the definition of successful treatment. Clinical Endocrinology 199338 73-78. (doi:10.1111/j.1365-2265.1993.tb00975.x)

14 Prevedello DM, Pouratian N, Sherman J, Jane JA Jr, Vance ML, Lopes MB \& Laws ER Jr. Management of Cushing's disease: outcome in patients with microadenoma detected on pituitary magnetic resonance imaging. Journal of Neurosurgery 2008109 751-759. (doi:10.3171/JNS/2008/109/10/0751)

15 Hammer GD, Tyrrell JB, Lamborn KR, Applebury CB, Hannegan ET, Bell S, Rahl R, Lu A \& Wilson CB. Transsphenoidal microsurgery for Cushing's disease: initial outcome and longterm results. Journal of Clinical Endocrinology and Metabolism 200489 6348-6357. (doi:10.1210/jc.2003-032180)

16 Hughes NR, Lissett CA \& Shalet SM. Growth hormone status following treatment for Cushing's syndrome. Clinical Endocrinology 199951 61-66. (doi:10.1046/j.1365-2265.1999. 00738.x)

17 Pecori Giraldi F, Andrioli M, De Marinis L, Bianchi A, Giampietro A, De Martin M, Sacco E, Scacchi M, Pontecorvi A \& Cavagnini F. Significant GH deficiency after long-term cure by surgery in adult patients with Cushing's disease. European Journal of Endocrinology 2007156 233-239. (doi:10.1530/eje. 1.02329)

18 Patil CG, Prevedello DM, Lad SP, Vance ML, Thorner MO, Katznelson L \& Laws ER Jr. Late recurrences of Cushing's disease after initial successful transsphenoidal surgery. Journal of Clinical Endocrinology and Metabolism 200893 358-362. (doi:10.1210/ jc. 2007-2013)

19 Atkinson AB, Kennedy A, Wiggam MI, McCance DR \& Sheridan B. Long-term remission rates after pituitary surgery for Cushing's disease: the need for long-term surveillance. Clinical Endocrinology 200563 549-559. (doi:10.1111/j.1365-2265. 2005.02380.x)

20 Bertagna X \& Guignat L. Approach to the Cushing's disease patient with persistent/recurrent hypercortisolism after pituitary surgery. Journal of Clinical Endocrinology and Metabolism 201398 1307-1318. (doi:10.1210/jc.2012-3200)

21 Plotz CM, Knowlton AI \& Ragan C. The natural history of Cushing's syndrome. American Journal of Medicine 195213 597-614. (doi:10.1016/0002-9343(52)90027-2)

22 Clayton RN, Raskauskiene D, Reulen RC \& Jones PW. Mortality and morbidity in Cushing's disease over 50 years in Stokeon-Trent, UK: audit and meta-analysis of literature. Journal of Clinical Endocrinology and Metabolism 201196 632-642. (doi:10.1210/jc.2010-1942)

23 Dekkers OM, Horvath-Puho E, Jorgensen JO, Cannegieter SC, Ehrenstein V, Vandenbroucke JP, Pereira AM \& Sorensen HT. Multisystem morbidity and mortality in Cushing's syndrome: a cohort study. Journal of Clinical Endocrinology and Metabolism 201398 2277-2284. (doi:10.1210/jc.2012-3582)

24 Dekkers OM, Biermasz NR, Pereira AM, Roelfsema F, van Aken MO, Voormolen JH \& Romijn JA. Mortality in patients 
treated for Cushing's disease is increased, compared with patients treated for nonfunctioning pituitary macroadenoma. Journal of Clinical Endocrinology and Metabolism 200792 976-981. (doi:10.1210/jc.2006-2112)

25 Mancini T, Kola B, Mantero F, Boscaro M \& Arnaldi G. High cardiovascular risk in patients with Cushing's syndrome according to $1999 \mathrm{WHO} / \mathrm{ISH}$ guidelines. Clinical Endocrinology 200461 768-777. (doi:10.1111/j.1365-2265.2004.02168.x)

26 Giordano R, Picu A, Marinazzo E, D’Angelo V, Berardelli R, Karamouzis I, Forno D, Zinna D, Maccario M, Ghigo E et al. Metabolic and cardiovascular outcomes in patients with Cushing's syndrome of different aetiologies during active disease and 1 year after remission. Clinical Endocrinology 201175354 360. (doi:10.1111/j.1365-2265.2011.04055.x)

27 Toja PM, Branzi G, Ciambellotti F, Radaelli P, De Martin M, Lonati LM, Scacchi M, Parati G, Cavagnini F \& Pecori Giraldi F. Clinical relevance of cardiac structure and function abnormalities in patients with Cushing's syndrome before and after cure. Clinical Endocrinology 201276 332-338. (doi:10.1111/j.13652265.2011.04206.x)

28 Pereira AM, Delgado V, Romijn JA, Smit JW, Bax JJ \& Feelders RA. Cardiac dysfunction is reversed upon successful treatment of Cushing's syndrome. European Journal of Endocrinology 2010162 331-340. (doi:10.1530/EJE-09-0621)

29 Yiu KH, Marsan NA, Delgado V, Biermasz NR, Holman ER, Smit JW, Feelders RA, Bax JJ \& Pereira AM. Increased myocardial fibrosis and left ventricular dysfunction in Cushing's syndrome. European Journal of Endocrinology $2012 \quad \mathbf{1 6 6} \quad 27-34$. (doi:10.1530/EJE-11-0601)

30 Faggiano A, Pivonello R, Spiezia S, De Martino MC, Filippella M, Di Somma C, Lombardi G \& Colao A. Cardiovascular risk factors and common carotid artery caliber and stiffness in patients with Cushing's disease during active disease and 1 year after disease remission. Journal of Clinical Endocrinology and Metabolism 2003 88 2527-2533. (doi:10.1210/jc.2002-021558)

31 Colao A, Pivonello R, Spiezia S, Faggiano A, Ferone D, Filippella M, Marzullo P, Cerbone G, Siciliani M \& Lombardi G. Persistence of increased cardiovascular risk in patients with Cushing's disease after five years of successful cure. Journal of Clinical Endocrinology and Metabolism $1999 \mathbf{8 4} 2664-2672$. (doi:10.1210/jc.84.8.2664)

32 Barahona MJ, Resmini E, Vilades D, Pons-Llado G, Leta R, Puig T \& Webb SM. Coronary artery disease detected by multislice computed tomography in patients after long-term cure of Cushing's syndrome. Journal of Clinical Endocrinology and Metabolism 201398 1093-1099. (doi:10.1210/jc.2012-3547)

33 Kristo C, Jemtland R, Ueland T, Godang K \& Bollerslev J. Restoration of the coupling process and normalization of bone mass following successful treatment of endogenous Cushing's syndrome: a prospective, long-term study. European Journal of Endocrinology 2006154 109-118. (doi:10.1530/eje.1.02067)

34 Vestergaard P, Lindholm J, Jorgensen JO, Hagen C, Hoeck HC, Laurberg P, Rejnmark L, Brixen K, Kristensen LO, FeldtRasmussen U et al. Increased risk of osteoporotic fractures in patients with Cushing's syndrome. European Journal of Endocrinology 2002146 51-56. (doi:10.1530/eje.0.1460051)

35 Barahona MJ, Sucunza N, Resmini E, Fernandez-Real JM, Ricart W, Moreno-Navarrete JM, Puig T, Wagner AM, RodriguezEspinosa J, Farrerons J et al. Deleterious effects of glucocorticoid replacement on bone in women after long-term remission of Cushing's syndrome. Journal of Bone and Mineral Research 2009 24 1841-1846. (doi:10.1359/jbmr.090505)

36 Hermus AR, Smals AG, Swinkels LM, Huysmans DA, Pieters GF, Sweep CF, Corstens FH \& Kloppenborg PW. Bone mineral density and bone turnover before and after surgical cure of Cushing's syndrome. Journal of Clinical Endocrinology and Metabolism 1995 80 2859-2865. (doi:10.1210/jc.80.10.2859)

37 Futo L, Toke J, Patocs A, Szappanos A, Varga I, Glaz E, Tulassay Z, Racz K \& Toth M. Skeletal differences in bone mineral area and content before and after cure of endogenous Cushing's syndrome. Osteoporosis International $2008 \mathbf{1 9}$ 941-949. (doi:10.1007/ s00198-007-0514-x)

38 Kawamata A, Iihara M, Okamoto T \& Obara T. Bone mineral density before and after surgical cure of Cushing's syndrome due to adrenocortical adenoma: prospective study. World Journal of Surgery 200832 890-896. (doi:10.1007/s00268-007-9394-7)

39 Lindsay JR, Nansel T, Baid S, Gumowski J \& Nieman LK. Longterm impaired quality of life in Cushing's syndrome despite initial improvement after surgical remission. Journal of Clinical Endocrinology and Metabolism 200691 447-453. (doi:10.1210/jc. 2005-1058)

40 Johnson MD, Woodburn CJ \& Vance ML. Quality of life in patients with a pituitary adenoma. Pituitary $2003 \quad 6 \quad 81-87$. (doi:10.1023/B:PITU.0000004798.27230.ed)

41 Sonino N \& Fava GA. Psychosomatic aspects of Cushing's disease. Psychotherapy and Psychosomatics $1998 \quad 67 \quad 140-146$. (doi:10.1159/000012274)

42 Loosen PT, Chambliss B, DeBold CR, Shelton R \& Orth DN. Psychiatric phenomenology in Cushing's disease. Pharmacopsychiatry 199225 192-198. (doi:10.1055/s-2007-1014405)

43 Fava GA, Morphy MA \& Sonino N. Affective prodromes of medical illness. Psychotherapy and Psychosomatics 199462 141-145. (doi:10.1159/000288916)

44 Whelan TB, Schteingart DE, Starkman MN \& Smith A. Neuropsychological deficits in Cushing's syndrome. Journal of Nervous and Mental Disease 1980168 753-757. (doi:10.1097/ 00005053-198012000-00008)

45 Starkman MN, Schteingart DE \& Schork MA. Correlation of bedside cognitive and neuropsychological tests in patients with Cushing's syndrome. Psychosomatics $1986 \quad 27 \quad 508-511$. (doi:10.1016/S0033-3182(86)72657-1)

46 Starkman MN, Gebarski SS, Berent S \& Schteingart DE. Hippocampal formation volume, memory dysfunction, and cortisol levels in patients with Cushing's syndrome. Biological Psychiatry $199232 \quad 756-765 . \quad$ (doi:10.1016/00063223(92)90079-F)

47 Simmons NE, Do HM, Lipper MH \& Laws ER Jr. Cerebral atrophy in Cushing's disease. Surgical Neurology 200053 72-76. (doi:10. 1016/S0090-3019(99)00197-4)

48 Wagenmakers MA, Netea-Maier RT, Prins JB, Dekkers T, den Heijer M \& Hermus AR. Impaired quality of life in patients in long-term remission of Cushing's syndrome of both adrenal and pituitary origin: a remaining effect of long-standing hypercortisolism? European Journal of Endocrinology 2012167 687-695. (doi:10.1530/EJE-12-0308)

49 Ragnarsson O, Berglund P, Eder DN \& Johannsson G. Long-term cognitive impairments and attentional deficits in patients with Cushing's disease and cortisol-producing adrenal adenoma in remission. Journal of Clinical Endocrinology and Metabolism 2012 97 E1640-E1648. (doi:10.1210/jc.2012-1945)

50 van Aken MO, Pereira AM, Biermasz NR, van Thiel SW, Hoftijzer HC, Smit JW, Roelfsema F, Lamberts SW \& Romijn JA. Quality of life in patients after long-term biochemical cure of Cushing's disease. Journal of Clinical Endocrinology and Metabolism 200590 3279-3286. (doi:10.1210/jc.2004-1375)

51 Hawn MT, Cook D, Deveney C \& Sheppard BC. Quality of life after laparoscopic bilateral adrenalectomy for Cushing's disease. Surgery 2002132 1064-1068 (discussion 1068-1069). (doi:10.1067/msy.2002.128482)

52 Jeffcoate WJ, Silverstone JT, Edwards CR \& Besser GM. Psychiatric manifestations of Cushing's syndrome: response to lowering of plasma cortisol. Quarterly Journal of Medicine 197948 465-472.

53 Dorn LD, Burgess ES, Friedman TC, Dubbert B, Gold PW \& Chrousos GP. The longitudinal course of psychopathology in Cushing's syndrome after correction of hypercortisolism. Journal of Clinical Endocrinology and Metabolism $1997 \mathbf{8 2}$ 912-919. (doi:10.1210/jc.82.3.912)

54 Tiemensma J, Biermasz NR, Middelkoop HA, van der Mast RC, Romijn JA \& Pereira AM. Increased prevalence of 
psychopathology and maladaptive personality traits after longterm cure of Cushing's disease. Journal of Clinical Endocrinology and Metabolism 201095 E129-E141. (doi:10.1210/jc.20100512)

55 Starkman MN, Giordani B, Gebarski SS \& Schteingart DE. Improvement in learning associated with increase in hippocampal formation volume. Biological Psychiatry $2003 \mathbf{5 3}$ 233-238. (doi:10.1016/S0006-3223(02)01750-X)

56 Dorn LD \& Cerrone P. Cognitive function in patients with Cushing syndrome: a longitudinal perspective. Clinical Nursing Research 20009 420-440. (doi:10.1177/10547730022158672)

57 Forget H, Lacroix A \& Cohen H. Persistent cognitive impairment following surgical treatment of Cushing's syndrome. Psychoneuroendocrinology $2002 \quad 27$ 367-383. (doi:10.1016/S03064530(01)00059-2)

58 Bourdeau I, Bard C, Noel B, Leclerc I, Cordeau MP, Belair M, Lesage J, Lafontaine L \& Lacroix A. Loss of brain volume in endogenous Cushing's syndrome and its reversibility after correction of hypercortisolism. Journal of Clinical Endocrinology and Metabolism 200287 1949-1954. (doi:10.1210/jc.87.5. 1949)

59 Starkman MN, Giordani B, Gebarski SS, Berent S, Schork MA \& Schteingart DE. Decrease in cortisol reverses human hippocampal atrophy following treatment of Cushing's disease. Biological Psychiatry 199946 1595-1602. (doi:10.1016/ S0006-3223(99)00203-6)

60 Tiemensma J, Kokshoorn NE, Biermasz NR, Keijser BJ, Wassenaar MJ, Middelkoop HA, Pereira AM \& Romijn JA. Subtle cognitive impairments in patients with long-term cure of Cushing's disease. Journal of Clinical Endocrinology and Metabolism 201095 2699-2714. (doi:10.1210/jc.2009-2032)

61 Resmini E, Santos A, Gomez-Anson B, Vives Y, Pires P, Crespo I, Portella MJ, de Juan-Delago M, Barahona MJ \& Webb SM. Verbal and visual memory performance and hippocampal volumes, measured by 3-tesla magnetic resonance imaging, in patients with Cushing's syndrome. Journal of Clinical Endocrinology and Metabolism 201297 663-671. (doi:10.1210/jc.2011-2231)

62 Merke DP, Giedd JN, Keil MF, Mehlinger SL, Wiggs EA, Holzer S, Rawson E, Vaituzis AC, Stratakis CA \& Chrousos GP. Children experience cognitive decline despite reversal of brain atrophy one year after resolution of Cushing syndrome. Journal of Clinical Endocrinology and Metabolism 200590 2531-2536. (doi:10.1210/jc.2004-2488)

63 Keil MF, Merke DP, Gandhi R, Wiggs EA, Obunse K \& Stratakis CA. Quality of life in children and adolescents 1-year after cure of Cushing syndrome: a prospective study. Clinical Endocrinology 200971 326-333. (doi:10.1111/j.1365-2265. 2008.03515.x)

64 Herbert J, Goodyer IM, Grossman AB, Hastings MH, de Kloet ER, Lightman SL, Lupien SJ, Roozendaal B \& Seckl JR. Do corticosteroids damage the brain? Journal of Neuroendocrinology 200618 393-411. (doi:10.1111/j.1365-2826.2006.01429.x)

65 Groeneweg FL, Karst H, de Kloet ER \& Joels M. Rapid nongenomic effects of corticosteroids and their role in the central stress response. Journal of Endocrinology 2011209 153-167. (doi:10.1530/JOE-10-0472)

66 Tata DA \& Anderson BJ. The effects of chronic glucocorticoid exposure on dendritic length, synapse numbers and glial volume in animal models: implications for hippocampal volume reductions in depression. Physiology \& Behavior 201099 186-193. (doi:10.1016/j.physbeh.2009.09.008)

67 Resmini E, Santos A, Gomez-Anson B, Lopez-Mourelo O, Pires P, Vives-Gilabert Y, Crespo I, Portella MJ, de Juan-Delago M \& Webb SM. Hippocampal dysfunction in cured Cushing's syndrome patients, detected by H-MR-spectroscopy. Clinical Endocrinology 2013. In press. (doi:10.1111/cen.12224)

68 Johansson P, Johansson JO, Labrie F, Mattsson N, Hansson O, Blennow K, Zetterberg H, Wallin A, Ohlsson C \& Svensson J. Mild dementia is associated with increased adrenal secretion of cortisol and precursor sex steroids in women. Clinical Endocrinology 201175 301-308. (doi:10.1111/j.1365-2265.2011. 04082.x)

69 Huang CW, Lui CC, Chang WN, Lu CH, Wang YL \& Chang CC. Elevated basal cortisol level predicts lower hippocampal volume and cognitive decline in Alzheimer's disease. Journal of Clinical Neuroscience 200916 1283-1286. (doi:10.1016/j.jocn.2008. 12.026)

70 Johansson P, Mattsson N, Hansson O, Wallin A, Johansson JO, Andreasson U, Zetterberg H, Blennow K \& Svensson J. Cerebrospinal fluid biomarkers for Alzheimer's disease: diagnostic performance in a homogeneous mono-center population. Journal of Alzheimer's Disease 201124 537-546. (doi:10.3233/ JAD-2011-101878)

71 Zetterberg H, Mattsson N \& Blennow K. Cerebrospinal fluid analysis should be considered in patients with cognitive problems. International Journal of Alzheimer's Disease 2010 2010 163065. (doi:10.4061/2010/163065)

72 Ragnarsson O, Berglund P, Eder DN, Zetterberg H, Hietala MA, Blennow K \& Johannsson G. Neurodegenerative and inflammatory biomarkers in cerebrospinal fluid in patients with Cushing's syndrome in remission. European Journal of Endocrinology 2013169 211-215. (doi:10.1530/EJE-13-0205)

73 Lambert JK, Goldberg L, Fayngold S, Kostadinov J, Post KD \& Geer EB. Predictors of mortality and long-term outcomes in treated Cushing's disease: a study of 346 patients. Journal of Clinical Endocrinology and Metabolism 201398 1022-1030. (doi:10.1210/jc.2012-2893)

74 Rollin GA, Ferreira NP, Junges M, Gross JL \& Czepielewski MA. Dynamics of serum cortisol levels after transsphenoidal surgery in a cohort of patients with Cushing's disease. Journal of Clinical Endocrinology and Metabolism $2004 \quad \mathbf{8 9}$ 1131-1139. (doi:10.1210/jc.2003-031170)

75 Lindsay JR, Oldfield EH, Stratakis CA \& Nieman LK. The postoperative basal cortisol and CRH tests for prediction of long-term remission from Cushing's disease after transsphenoidal surgery. Journal of Clinical Endocrinology and Metabolism 2011 96 2057-2064. (doi:10.1210/jc.2011-0456)

76 Esposito F, Dusick JR, Cohan P, Moftakhar P, McArthur D, Wang C, Swerdloff RS \& Kelly DF. Clinical review: Early morning cortisol levels as a predictor of remission after transsphenoidal surgery for Cushing's disease. Journal of Clinical Endocrinology and Metabolism 200691 7-13. (doi:10.1210/jc.2005-1204)

77 Klose M, Jorgensen K \& Kristensen LO. Characteristics of recovery of adrenocortical function after treatment for Cushing's syndrome due to pituitary or adrenal adenomas. Clinical Endocrinology 200461 394-399. (doi:10.1111/j.1365-2265.2004. 02111.x)

78 Estrada J, Garcia-Uria J, Lamas C, Alfaro J, Lucas T, Diez S, Salto L \& Barcelo B. The complete normalization of the adrenocortical function as the criterion of cure after transsphenoidal surgery for Cushing's disease. Journal of Clinical Endocrinology and Metabolism 200186 5695-5699. (doi:10.1210/jc.86.12.5695)

79 Lodish M, Dunn SV, Sinaii N, Keil MF \& Stratakis CA. Recovery of the hypothalamic-pituitary-adrenal axis in children and adolescents after surgical cure of Cushing's disease. Journal of Clinical Endocrinology and Metabolism $2012 \quad \mathbf{9 7}$ 1483-1491. (doi:10.1210/jc.2011-2325)

80 Bhattacharyya A, Kaushal K, Tymms DJ \& Davis JR. Steroid withdrawal syndrome after successful treatment of Cushing's syndrome: a reminder. European Journal of Endocrinology 2005 153 207-210. (doi:10.1530/eje.1.01953)

81 Dahlqvist P, Bensing S, Ekwall O, Wahlberg J, Bergthorsdottir R \& Hulting AL. A national medical emergency card for adrenal insufficiency. A new warning card for better management and patient safety. Lakartidningen $2011 \mathbf{1 0 8} 2226-2227$.

82 Odagiri E, Yamanaka Y, Ishiwatari N, Jibiki K, Demura R, Demura H, Suda T \& Shizume K. Studies on pituitary-gonadal function in patients with Cushing's syndrome. Endocrinologia Japonica 198835 421-427. (doi:10.1507/endocrj1954.35.421) 
83 Mathioudakis N, Thapa S, Wand GS \& Salvatori R. ACTHsecreting pituitary microadenomas are associated with a higher prevalence of central hypothyroidism compared to other microadenoma types. Clinical Endocrinology 201277 871-876. (doi:10.1111/j.1365-2265.2012.04442.x)

84 Marazuela M, Cuerda C, Lucas T, Vicente A, Blanco C \& Estrada J. Anterior pituitary function after adrenalectomy in patients with Cushing's syndrome. Postgraduate Medical Journal 199369 547-551. (doi:10.1136/pgmj.69.813.547)

85 Luton JP, Thieblot P, Valcke JC, Mahoudeau JA \& Bricaire H. Reversible gonadotropin deficiency in male Cushing's disease. Journal of Clinical Endocrinology and Metabolism $1977 \quad 45$ 488-495. (doi:10.1210/jcem-45-3-488)

86 Stratakis CA, Mastorakos G, Magiakou MA, Papavasiliou E, Oldfield EH \& Chrousos GP. Thyroid function in children with Cushing's disease before and after transsphenoidal surgery. Journal of Pediatrics 1997131 905-909. (doi:10.1016/S00223476(97)70041-6)

87 Doherty GM, Nieman LK, Cutler GB Jr, Chrousos GP \& Norton JA. Time to recovery of the hypothalamic-pituitary-adrenal axis after curative resection of adrenal tumors in patients with Cushing's syndrome. Surgery 1990108 1085-1090.

88 Tan HS, Thai AC, Nga ME \& Mukherjee JJ. Development of ipsilateral adrenocortical carcinoma sixteen years after resection of an adrenal tumour causing Cushing's syndrome. Annals of the Academy of Medicine, Singapore 200534 271-274.

89 Meyer A \& Behrend M. Cushing's syndrome: adrenalectomy and long-term results. Digestive Surgery 200421 363-370. (doi:10.1159/000081353)

90 Sherlock M, Ayuk J, Tomlinson JW, Toogood AA, AragonAlonso A, Sheppard MC, Bates AS \& Stewart PM. Mortality in patients with pituitary disease. Endocrine Reviews 201031 301-342. (doi:10.1210/er.2009-0033)

91 Rosen T \& Bengtsson BA. Premature mortality due to cardiovascular disease in hypopituitarism. Lancet $1990 \mathbf{3 3 6}$ 285-288. (doi:10.1016/0140-6736(90)91812-0)

92 Svensson J, Bengtsson BA, Rosen T, Oden A \& Johannsson G. Malignant disease and cardiovascular morbidity in hypopituitary adults with or without growth hormone replacement therapy. Journal of Clinical Endocrinology and Metabolism 2004893306 3312. (doi:10.1210/jc.2003-031601)

93 Brada M, Ashley S, Ford D, Traish D, Burchell L \& Rajan B. Cerebrovascular mortality in patients with pituitary adenoma. Clinical Endocrinology 200257 713-717. (doi:10.1046/j.13652265.2002.01570.x)

94 Gaillard RC, Mattsson AF, Akerblad AC, Bengtsson BA, Cara J, Feldt-Rasmussen U, Koltowska-Haggstrom M, Monson JP, Saller B, Wilton P et al. Overall and cause-specific mortality in GH-deficient adults on GH replacement. European Journal of Endocrinology 2012 166 1069-1077. (doi:10.1530/EJE-11-1028)

95 Tzanela M, Karavitaki N, Stylianidou C, Tsagarakis S \& Thalassinos NC. Assessment of GH reserve before and after successful treatment of adult patients with Cushing's syndrome. Clinical Endocrinology 200460 309-314. (doi:10.1046/j.13652265.2004.01976.x)

96 Hoybye C, Ragnarsson O, Jonsson PJ, Koltowska-Haggstrom M, Trainer P, Feldt-Rasmussen U \& Biller BM. Clinical features of GH deficiency and effects of 3 years of GH replacement in adults with controlled Cushing's disease. European Journal of Endocrinology 2010162 677-684. (doi:10.1530/EJE-09-0836)

97 Falleti MG, Maruff P, Burman P \& Harris A. The effects of growth hormone $(\mathrm{GH})$ deficiency and $\mathrm{GH}$ replacement on cognitive performance in adults: a meta-analysis of the current literature. Psychoneuroendocrinology 200631 681-691. (doi:10.1016/j. psyneuen.2006.01.005)

98 Oertel H, Schneider HJ, Stalla GK, Holsboer F \& Zihl J. The effect of growth hormone substitution on cognitive performance in adult patients with hypopituitarism. Psychoneuroendocrinology 2004 29 839-850. (doi:10.1016/S0306-4530(03)00151-3)

99 Bensing S, Brandt L, Tabaroj F, Sjoberg O, Nilsson B, Ekbom A, Blomqvist P \& Kampe O. Increased death risk and altered cancer incidence pattern in patients with isolated or combined autoimmune primary adrenocortical insufficiency. Clinical Endocrinology 200869 697-704. (doi:10.1111/j.1365-2265.2008.03340.x)

100 Bergthorsdottir R, Leonsson-Zachrisson M, Oden A \& Johannsson G. Premature mortality in patients with Addison's disease: a population-based study. Journal of Clinical Endocrinology and Metabolism 200691 4849-4853. (doi:10.1210/jc.2006-0076)

101 Sherlock M, Reulen RC, Alonso AA, Ayuk J, Clayton RN, Sheppard MC, Hawkins MM, Bates AS \& Stewart PM. ACTH deficiency, higher doses of hydrocortisone replacement, and radiotherapy are independent predictors of mortality in patients with acromegaly. Journal of Clinical Endocrinology and Metabolism 200994 4216-4223. (doi:10.1210/jc.2009-1097)

102 Esteban NV, Loughlin T, Yergey AL, Zawadzki JK, Booth JD, Winterer JC \& Loriaux DL. Daily cortisol production rate in man determined by stable isotope dilution/mass spectrometry. Journal of Clinical Endocrinology and Metabolism 199172 39-45. (doi:10.1210/jcem-72-1-39)

103 Filipsson H, Monson JP, Koltowska-Haggstrom M, Mattsson A \& Johannsson G. The impact of glucocorticoid replacement regimens on metabolic outcome and comorbidity in hypopituitary patients. Journal of Clinical Endocrinology and Metabolism 200691 3954-3961. (doi:10.1210/jc.2006-0524)

104 Ragnarsson O, Nystrom HF \& Johannsson G. Glucocorticoid replacement therapy is independently associated with reduced bone mineral density in women with hypopituitarism. Clinical Endocrinology 201276 246-252. (doi:10.1111/j.1365-2265. 2011.04174.x)

105 Zelissen PM, Croughs RJ, van Rijk PP \& Raymakers JA. Effect of glucocorticoid replacement therapy on bone mineral density in patients with Addison disease. Annals of Internal Medicine 1994 120 207-210. (doi:10.7326/0003-4819-120-3-199402010$00005)$

106 Bleicken B, Hahner S, Loeffler M, Ventz M, Decker O, Allolio B \& Quinkler M. Influence of hydrocortisone dosage scheme on health-related quality of life in patients with adrenal insufficiency. Clinical Endocrinology 201072 297-304. (doi:10.1111/j. 1365-2265.2009.03596.x)

107 Hahner S, Loeffler M, Fassnacht M, Weismann D, Koschker AC, Quinkler M, Decker O, Arlt W \& Allolio B. Impaired subjective health status in 256 patients with adrenal insufficiency on standard therapy based on cross-sectional analysis. Journal of Clinical Endocrinology and Metabolism $2007923912-3922$. (doi:10.1210/jc.2007-0685)

108 Johannsson G, Nilsson AG, Bergthorsdottir R, Burman P, Dahlqvist P, Ekman B, Engstrom BE, Olsson T, Ragnarsson O, Ryberg $\mathrm{M}$ et al. Improved cortisol exposure-time profile and outcome in patients with adrenal insufficiency: a prospective randomized trial of a novel hydrocortisone dual-release formulation. Journal of Clinical Endocrinology and Metabolism 201297 473-481. (doi:10.1210/jc.2011-1926)

109 Burman P, Mattsson AF, Johannsson G, Hoybye C, Holmer H, Dahlqvist P, Berinder K, Engstrom BE, Ekman B, Erfurth EM et al. Deaths among adult patients with hypopituitarism: hypocortisolism during acute stress, and de novo malignant brain tumors contribute to an increased mortality. Journal of Clinical Endocrinology and Metabolism 201398 1466-1475. (doi:10.1210/jc. 2012-4059)

110 Buse JB, Ginsberg HN, Bakris GL, Clark NG, Costa F, Eckel R, Fonseca V, Gerstein HC, Grundy S, Nesto RW et al. Primary prevention of cardiovascular diseases in people with diabetes mellitus: a scientific statement from the American Heart Association and the American Diabetes Association. Diabetes Care 200730 162-172. (doi:10.2337/dc07-9917)

111 Biochemical assessment and long-term monitoring in patients with acromegaly: statement from a joint consensus conference of the Growth Hormone Research Society and the Pituitary Society. Journal of Clinical Endocrinology and Metabolism $2004 \mathbf{8 9}$ 3099-3102. (doi:10.1210/jc.2003-031138) 
112 Peacey SR, Guo CY, Robinson AM, Price A, Giles MA, Eastell R \& Weetman AP. Glucocorticoid replacement therapy: are patients over treated and does it matter? Clinical Endocrinology $1997 \mathbf{4 6}$ 255-261. (doi:10.1046/j.1365-2265.1997.780907.x)

113 Wuster C, Abs R, Bengtsson BA, Bennmarker H, Feldt-Rasmussen U, Hernberg-Stahl E, Monson JP, Westberg B \& Wilton P. The influence of growth hormone deficiency, growth hormone replacement therapy, and other aspects of hypopituitarism on fracture rate and bone mineral density. Journal of Bone and Mineral Research 200116 398-405. (doi:10.1359/jbmr.2001.16.2.398)

114 Holmes SJ, Economou G, Whitehouse RW, Adams JE \& Shalet SM. Reduced bone mineral density in patients with adult onset growth hormone deficiency. Journal of Clinical Endocrinology and Metabolism 199478 669-674. (doi:10.1210/jc.78.3.669)

115 Doga M, Bonadonna S, Gola M, Mazziotti G, Nuzzo M \& Giustina A. GH deficiency in the adult and bone. Journal of Endocrinological Investigation $2005 \mathbf{2 8} 18-23$.

116 Tritos NA, Greenspan SL, King D, Hamrahian A, Cook DM, Jonsson PJ, Wajnrajch MP, Koltowska-Haggstrom M \& Biller BM. Unreplaced sex steroid deficiency, corticotropin deficiency, and lower IGF-I are associated with lower bone mineral density in adults with growth hormone deficiency: a KIMS database analysis. Journal of Clinical Endocrinology and Metabolism 2011 96 1516-1523. (doi:10.1210/jc.2010-2662)

117 Tiemensma J, Kaptein AA, Pereira AM, Smit JW, Romijn JA \& Biermasz NR. Coping strategies in patients after treatment for functioning or nonfunctioning pituitary adenomas. Journal of Clinical Endocrinology and Metabolism 201196 964-971. (doi:10.1210/jc.2010-2490)

118 Mauri M, Sinforiani E, Bono G, Vignati F, Berselli ME, Attanasio R \& Nappi G. Memory impairment in Cushing's disease. Acta Neurol Scand $19938752-55$.

119 Hook JN, Giordani B, Schteingart DE, Guire K, Giles J, Ryan K, Gebarski SS, Langenecker SA \& Starkman MN. Patterns of cognitive change over time and relationship to age following successful treatment of Cushing's disease. J Int Neuropsychol Soc $20071321-29$.

Received 28 June 2013

Revised version received 20 August 2013

Accepted 23 August 2013 